swims back to the island in a downpour. The villagers gather like children on the banks and weakly wave to him. The whir of insects stops. The birds flock and fly away. The monkeys wobble to the river, the first to drown themselves.

He has another eye now, and a patch. Each day he walks his island. He wears his coat. He thinks about rescue and the homeward flight.

POETRY / B ROW N, HEAD, C UDDIH Y

\title{
The Desertion of the Women and Seals /
}

\section{George Mackay Brown}

Howie gave sentence of slaughter

To the fifty seals on the skerry.

For a month now the inland lasses,

Bella, Jemima, Mary

And Hundaskaill's cold beautiful daughter

-It was said, because of his hard grudging fist-

Denied their kisses.

A month he watched the drift of seals in the west.

A clean gale out of the sunset

Would cancel scent and sound

But make those creatures vivid upon the floods.

'Maybe,' thought Howie, 'a pound

Or thirty shillings, for powder and shot ....'

He would change the flock to bag and slipper and broochEntrancing gauds-

And gather the spendthrift girls back to his couch.

That sunset, shrug after shrug

The seals abandoned the shore.

Across the sacrificial rock

Drifted a delicate smirr,

Tresses of haar, a fleece of fog.

It scarfed in one cold weave the selkie-flight.

Then, rook by rook

Round Howie's impotence drew in the night. 